\title{
RANCANG BANGUN SISTEM INFORMASI PENJUALAN DAN PRIORITAS PENGADAAN BARANG BERBASIS WEB DENGAN METODE PROMETHEE
}

\author{
Fian Hidayah Nurprayogi *, Achmad Teguh Wibowo**, Mohammad Khusnu Milad *** \\ $*, * *, * * *$ Fakultas Sains dan Teknologi, UIN Sunan Ampel Suraba \\ *fichajakson@gmail.com,**atw@uinsby.ac.id,***m.milad@uinsby.ac.id
}

\begin{abstract}
This research discussed the usefulness of the promethee method to solve one of the problems that commonly occur in UD Motto Racing Surabaya. Problems at UD. Motto Racing Surabaya which is still using a manual system in determining the priority of procurement. One alternative solution to this problem is to build a system that can directly produce recommendations to determine the priority of procurement. So that it can minimize errors in the re-stock of goods that result in consumers disappointed. With the existence of this sales information system and priority of procurement of web-based, can help leaders in making decisions for the procurement of goods because comfort and customer satisfaction are the main keys to the company. The results obtained are the priority recommendations for the procurement of goods to be more accurate than without using the system, as evidenced from the results of accuracy testing in the number of April percentages of $66.67 \%$, May percentages of $83.33 \%$, June percentages of $50 \%$ and July percentages of $83.33 \%$.
\end{abstract}

Keyword: Sales, Procurement of goods, Promethee

\section{Pendahuluan}

UD. Motto Racing merupakan salah satu perusahaan distributor di bidang produk variasi sepeda motor di wilayah Surabaya. UD. Motto Racing menjual berbagai jenis variasi untuk sepeda motor mulai dari fairing hingga lampu sepeda motor. Pihak toko harus melakukan pemesanan barang kepada supplier dalam memenuhi permintaan konsumen dimana terkadang barang yang dipesan kurang dalam memenhui kebutuhan konsumen serta juga kesulitan untuk memprioritaskan barang mana yang harus direstock terlebih dahulu agar tetap bisa memenuhi kebutuhan konsumen.

Permasalahan yang terjadi di UD. Motto Racing adalah, dalam pengelolaan data barang masih menggunakan cara manual dengan menulis ke dalam buku catatan. Selama ini admin melakukan pengecekan barang setiap harinya untuk memastikan jumlah stock setiap barang. Proses pengecekan seperti ini membutuhkan waktu yang sangat lama dan rentan terhadap kesalahan sehingga harus kerja dua kali atau bahkan lebih dalam perhitungan stock barang.

Permasalahan lain adalah tidak adanya prioritas perkiraan barang yang harus di restock terlebih dahulu. sehingga pembelian barang dari supplier sering keliru, dan tak jarang ada beberapa pelanggan yang kecewa karena barang yang dipesan tidak tersedia, bahkan tidak sedikit pula barang yang tersedia berlebih yang dapat menyebabkan toko harus mengeluarkan biaya tambahan untuk penyimpanan dan pemeliharaan guna menjaga kualitas barang.

Dalam penelitian dengan judul Implementasi Metode Promethee II untuk Menentukan Pemenang Tender Proyek (Studi Kasus: Dinas Perhubungan dan LLAJ Provinsi Jawa Timur). Meneliti tentang Sistem penentuan pemilihan pemenang tender pada Dinas Perhubungan dan LLAJ Provinsi Jawa Timur dengan metode promethee dengan hasil dari pengujian akurasi sistem penentuan pemilihan pemenang tender menggunakan metode promethee memiliki tingkat akurasi tertinggi pada penggunaan tipe preferensi usual criterion dan quansi criterion yaitu sebesar $84.210 \%$, sedangkan pada penggunaan tipe preferensi level criterion mencapai nilai terendah sebesar $63.157 \%$. Nilai akurasi tersebut dipengaruhi oleh beberapa faktor, diantaranya tipe preferensi yang digunakan sebagai pengujian, jumlah data yang digunakan, dan juga perubahan nilai bobot yang mempengaruhi tingkat akurasi sistem, metode Promthee menujukkan efektifitas yang baik dalam menyelesaikan masalah pendukung keputusan dengan multi kriteria [1].

Jurnal dengan judul A PROMETHEE-FLP Method for Heterogeneous Multi-Attributes Group Decision Making [2]. Dimana riset ini membahas tentang multi-attribute group decision-making (MAGDM), menggunakan fuzzy set intuitionistic digunakan untuk mewakili penilaian alternatif, informasi bobot atribut 
tidak lengkap dan bobot pembuat keputusan tidak diketahui dan Promethee untuk pemeringkatan alternatif. Hasil dari riset ini mengusulkan metode baru yaitu fuzzy PROMETHEE-FLP yang dapat secara efektif menyelesaikan masalah MAGDM dengan format informasi heterogen yang melibatkan bilangan real, IFS, interval, TIFNs dan TrIFNs, dan bobot informasi tidak lengkap.Penelitian selanjutnya dengan judul A Novel PROMETHEE-Based Outranking Approach for Multiple Criteria Decision Analysis With Pythagorean Fuzzy Information[3]. Dimana penelitian ini membahas tentang pembaruan pendekatan outrangking dari PROMETHEE dan Pythagorean fuzzy untuk multiple criteria decision analysis (MCDA).Hasil dari penelitian ini metode PROMETHEE dan Pythagorean fuzzy dapat menangani informasi ambigu yang menjadi kelemahan di MCDA, karena PROMETHEE dan Pythagorean fuzzy memungkinkan fleksibilitas yang lebih besar dalam hal keanggotaan dan derajat non-keanggotaan dengan memperluas ruang representasi.

Lebih lanjut lagi Environmental Criteria for Assessing the Competitiveness of Public Tenders with the Replacement of Large-Scale LEDs in the Outdoor Lighting of Cities as a Key Element for Sustainable Development: Case Study Applied with PROMETHEE Methodology [4]. Dimana penelitian ini membahas tentang proses pemilihan LED luminer dengan metode Promethee termasuk penilaian dampak lingkungan dengan Teknik LCA. Hasil dari penelitian ini metodologi PROMETHEE digunakan dalam proses seleksi untuk menjabarkan spesifikasi penerangan jalan umum dengan environmental criteria.

Selanjutnya penelitian dengan judul Failure Mode and Effect Analysis Using Cloud Model Theory and PROMETHEE Method [5].Dimana penelitian ini membahas tentang Failure mode and effect analysis (FMEA) yang merupakan teknik rekayasa untuk mengenali dan mengurangi kemungkinan kegagalan untuk peningkatan kualitas dan keandalan produk dan jasa, metode PROMETHEE digunakan untuk mengatasi ketidakjelasan dan keacakan di FMEA. Hasil dari penelitian tersebut bahwa PROMETHEE dapat mengatasi kelemahan dari FMEA dan menignkatkan kepraktisan dak efektifitas dari perangkingan resiko.

Berikutnya penelitian dengan judul Multicriteria Evaluation of Urban Regeneration Processes: An Application of PROMETHEE Method in Northern Italy[6].Dimana penelitian ini membahas tentang pengambaran tentang pengembangan model evaluasi untuk mendukung proses pengambilan keputusan terkait dengan intervensi regenerasi perkotaan, penelitian ini mengusulkan pendekatan multi-metodologi yang menggabungkan SWOT Analisis, analisis konsumen dan PROMETHEE, untuk evaluasi strategi pembaruan alternatif suatu daerah perkotaan di Italia Utara. Hasil dari penelitian ini PROMETHEE dapat diimplementasikan dalam pengambilan keputusan terkait perencanaan dan pengembangan kota, metode PROMETHEE digunakan untuk menentukan prioritas proyek.

PROMETHEE merupakan metode yang sederhana dengan proses perhitungan dan analisis yang jelas sehingga diharapkan PROMETHEE dapat memberikan solusi untuk permasalahan dalam menentukan prioritas pengadaan barang. PROMETHEE melakukan perankingan dengan mempertimbangkan nilai leaving flow merupakan nilai tertinggi dibanding nilai data lainnya dan entering flow merupakan nilai yang terendah lalu akan terjadi perankingan data-data alternatif. PROMETHEE merupakan pengembangan dari metode PROMETHEE dengan mempertimbangkan nilai netflow dalam proses perankingan[1].

Berdasarkan permasalahan yang dihadapi oleh UD. Motto Racing, diperlukan suatu metode yang dapat mempertimbangkan seluruh kriteria sehingga pihak UD. Motto Racing dapat mengambil keputusan untuk memprioritas pengadaan barang yang akan di restock terlebih dahulu.

\section{Metodologi}

\subsection{Promethee}

Metode Promethee pertama kali dikembangkan oleh JP.Brans dan dipublikasikan pada tahun 1982 pada sebuah konferensi yang diorganisasikan R.Nadeau dan M.Landry di Universitas Laval, Quebec Canada. Preference Ranking Organization Method For Enrichment Evaluation (Promethee) salah satu metode penentuan urutan atau prioritas dalam analisis multikriteria atau Multi Criterion Decision Making (MCDM). Dugaan dari dominasi kriteria yang digunakan dalam promethee adalah penggunaan nilai dalam hubungan outrangking. Masalah pokoknya adalah kesederhanaan, kejelasan dan kestabilan[7].

Fungsi preferensi kriteria promethee yang digunakan adalah linear dan linear quasi. Dimana persamaan linear adalah sebagai berikut:

\subsection{Desain penelitian}

Desain penelitian ini dapat digambarkan menggunakan dengan diagram alur flowcart. Hal ini dilakukan peneliti agar mempermudah peneliti dalam melakukan alur penelitian. Berikut adalah diagram alur flowchartnya: 


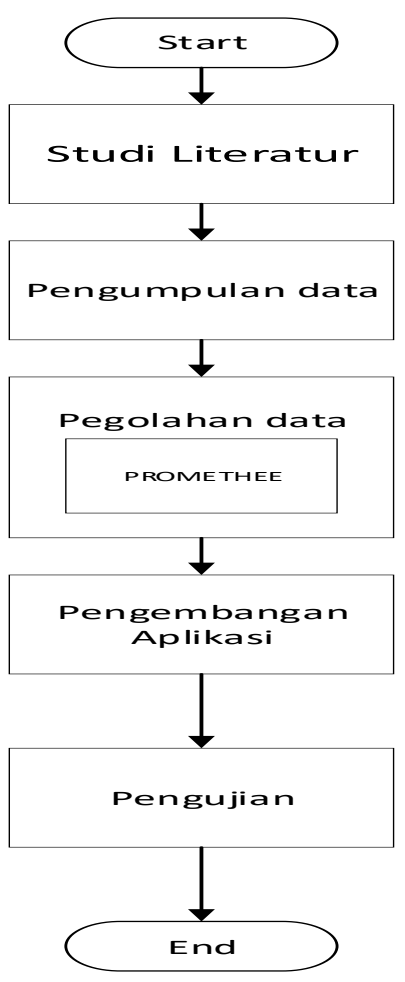

\subsection{Studi Literatur}

Gambar 1. Flowchart Desain Penelitian

Studi literatur bertujuan untuk menyusun atau menyiapkan dasar teori apa saja yang nantinya akan digunakan dalam penelitian kali ini. Sumber yang dapat digunakan sebagai studi literatur contohnya seperti buku, jurnal, internet dan dokumen-dokumen yang terkait dengan penjualan dan pengadaan barang.

\subsection{Pengumpulan Data}

- Wawancara

Salah satu cara untuk mengumpulkan data adalah dengan melakukan wawancara dengan menanyakan langsung kepada narasumber. Dalam penelitian yang akan dilakukan kali ini peneliti akan melakukan wawancara secara langsung kepada pemilik UD.Motto Racing Surabaya.

- Dokumentasi

Dokumentasi adalah teknik pengambilan data dengan cara membaca dan juga mengambil kesimpulan dari berkas-berkas yang terjadi dalam penentuan prioritas pengadaan barang yang ada di UD Motto Racing Surabaya.

\subsection{Pengolahan Data}

Setelah data terkumpul, perlu adanya tahapan-tahapan dalam pengolahan data, berikut adalah tahap pengolahan data yaitu, menentukan alternatif, menentukan kriteria, menentukan dominasi kriteria atau pembobotan, menentukan tipe preferensi untuk setiap kriteria. Fungsi preferensi kriteria promethee yang digunakan adalah linear, linear quasi dan perrhitungan net flow. Untuk mengolah data menggunakan persamaan sebagai berikut

$$
\begin{gathered}
H(d)=\left\{\begin{array}{cc}
0 & |d| \leq q \\
\frac{|d|-q}{p-q} & q<|d| \leq p \\
1 & |d|>p
\end{array}\right. \\
H(d)= \begin{cases}\frac{|d|}{p} & |d| \leq p \\
1 & |d|>p\end{cases} \\
\varphi(a)=\varphi^{+}(a)-\varphi^{-}(a)
\end{gathered}
$$




\subsection{Metode Pengembangan}

Metode pengembangan berarti susunan cara untuk mengembangkan sebuah produk atau aplikasi. Dengan adanya metode pengembangan diharapkan produk atau aplikasi yang dikembangkan dapat dibuat dengan cepat dan juga tepat.

Pada penelitian kali ini menggunakan Intructional Design (Desain Pembelajaran) yang dikembangkan oleh Robert Maribe Brach (2009) dengan pendekatan Analysis, Design Development, Implementation, and Evaluation (ADDIE). Karena metode ini merupakan cara penelitian yang sangat elastis dalam penerapannya. Yang dimaksud elastis adalah antara tahapan satu dengan yang lain dapat langsung dievaluasi dan direvisi sesuai dengan kondisi dilapangan.

\subsection{Pengujian Sistem}

Setelah tahap pengembangan sistem kemudian sistem tersebut akan di uji dengan cara membandingkan hasil dari sistem yang telah dibuat dengan data real yang telah didapat, kemudian menggunakan metode pengujian akurasi. Akurasi adalah keakuratan data yang dihasilkan oleh perhitungan sistem dengan data yang seharusnya diminta atau data real

\section{Hasil Pembahasan}

Pada penelitian yang dilakukan kali ini metode yang digunakan dalam sistem pendukung keputusan adalah promethee untuk penentuan prioritas pengadaan barang. Setelah data terkumpul, perlu adanya pengolahan data dengan tahapan-tahapan sebagai berikut :

\subsection{Menentukan Alternatif}

Dalam penelitian tentang sistem pendukung keputusan, alternatif merupakan bahan utama yang sangat diperlukan. Dengan demikian perlu adanya sebuah data yang kongkret dan berkualitas untuk terciptanya penelitian yang bermutu. Pada perhitungan penyeleksian dengan promethee diperlukan penentuan beberapa obyek yang akan diseleksi (minimal 2 obyek).

\subsection{Menentukan Kriteria}

Setelah melakukan penentuan obyek yang akan diseleksi, maka dalam perhitungan penyeleksian promethee juga diperlukan penentuan beberapa kriteria, penentuan kriteria disini sebagai syarat atau ketentuan dalam penyeleksian. Adapun penentuan kriteria dilakukan dalam penelitian ini adalah sebagai berikut :

1. Kriteria bersumber dari hasil wawancara terhadap pimimpinan UD. Motto Racing Surabaya

2. Kriteria yang dipilih disesuaikan dengan kondisi penjualan di UD. Motto Racing Surabaya.

\subsection{Menentukan Dominasi Kriteria atau Pembobotan}

Menentukan bobot atau dominasi kriteria dari kriteria lainnya. Setiap kriteria boleh memiliki nilai bobot yang sama atau berbeda, berikut adalah kriteria dan bobot:

1. Jumlah barang yang terjual dalam 1 bulan dengan bobot $60 \%$

2. Stok barang yang berada di gudang dengan bobot $25 \%$

3. Harga beli barang dengan bobot $15 \%$

\subsection{Use Case Diagram}

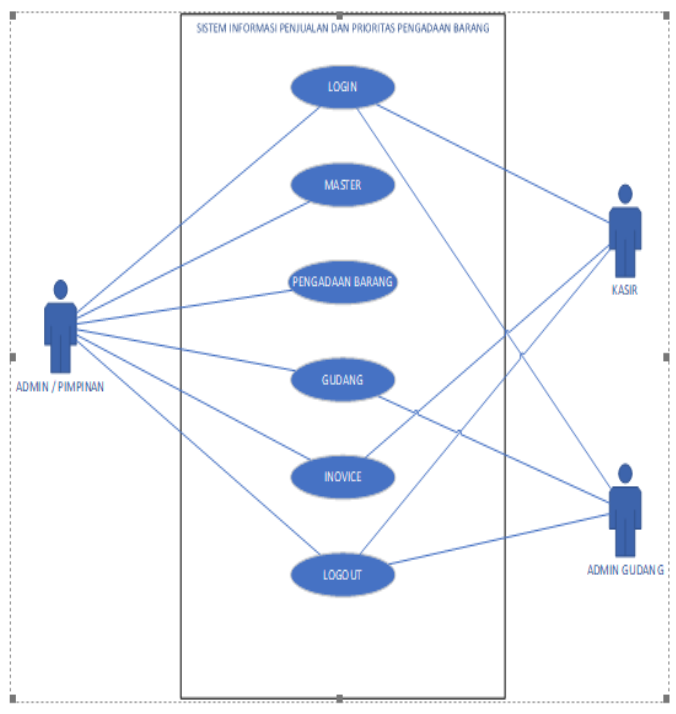

Gambar 2. Use Case Diagram 
Dalam use case gambar 1 tersebut terlihat bahwa ada 3 aktor yang menggunakan sistem tersebut yaitu Admin / Pimpinan, Admin gudang, dan Kasir. Aktor Kasir dalam sistem tersebut bisa login selanjutnya aktor kasir hanya bisa mencatat atau mengelola data penjualan (Invoice) termasuk mencetak struk / nota penjualan barang dan terkahir aktor kasir juga bisa logout.

Aktor kedua adalah admin gudang pada sistem ini aktor admin gudang setelah login mempunyai hak untuk melakukan segala sesuatu terkait gudang(inventory) termasuk menyetujui barang keluar setelah selesai melakukan pesanan, juga aktor admin gudang mempunyai wewenang untuk meng-inputkan barang masuk dan yang terakhir aktor admin gudang dapat logout.

Aktor terakhir adalah Admin / pimpinan yang mempunyai segala hak akses dalam sistem ini ternasuk hak akses dari aktor Admin gudang dan kasir, aktor Admin / Pimpinan dapat mengiputkan data - data master seperti data produk, data user, data cabang, dan juga data pelanggan selai itu aktor Admin / Pimpinan dapat.

\subsection{Activity Diagram}

Activity diagram menu invoice adalah alur untuk menambahkan atau mengelola invoice yang ada, pertama user admin / pimpinan ataupun kasir harus login terlebih dahulu setelah itu masuk ke menu invoice dan langsung akan muncul data invoice yang telah tercatat, langkah selanjutnya menambahkan invoice yang baru dengan mengisi barang apa saja yang akan dibeli nama pelanggan, alamat pelanggan dan juga jumlah uang yang dibayarkan oleh pelanggan, jika barang yang dipilih sudah sesuai dengan yang dipesan dan juga semua data pelanggan sudah lengkap maka tinggal klik tombol simpan. Jika sudah di klik maka akan ada pilihan untuk cetak bukti invoice atau nota penjualan yang ditunjukkan pada gambar 3(a).

Sedangkan activity diagram menu gudang adalah alur untuk mencatat keluar ataupun masuknya di gudang, pertama admin gudang harus melakukan login ke sistem setelah memilih menu gudang, selanjutnya admin gudang akan mengisi form terkait barang keluar atau barang masuk serta jumlah barangnya jika barang yang akan keluar lebih besar dari pada yang ada digudang maka barang tersebut tidak bisa disetujui atau tidak bisa dikeluarkan dari gudang, setelah menginputkan barang keluar atau barang masuk maka akan muncul notifikasi / pemberitahuan barang telah masuk atau barang telah disetujui ditunjukkan pada gambar 3(b).

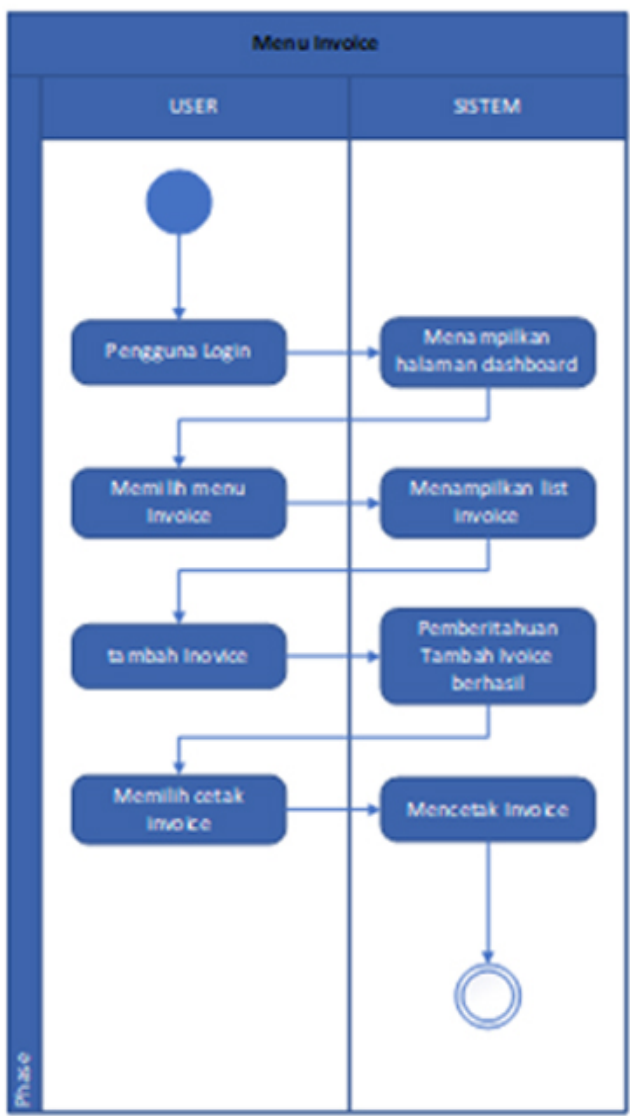

(a) Activity Diagram Menu Invoice

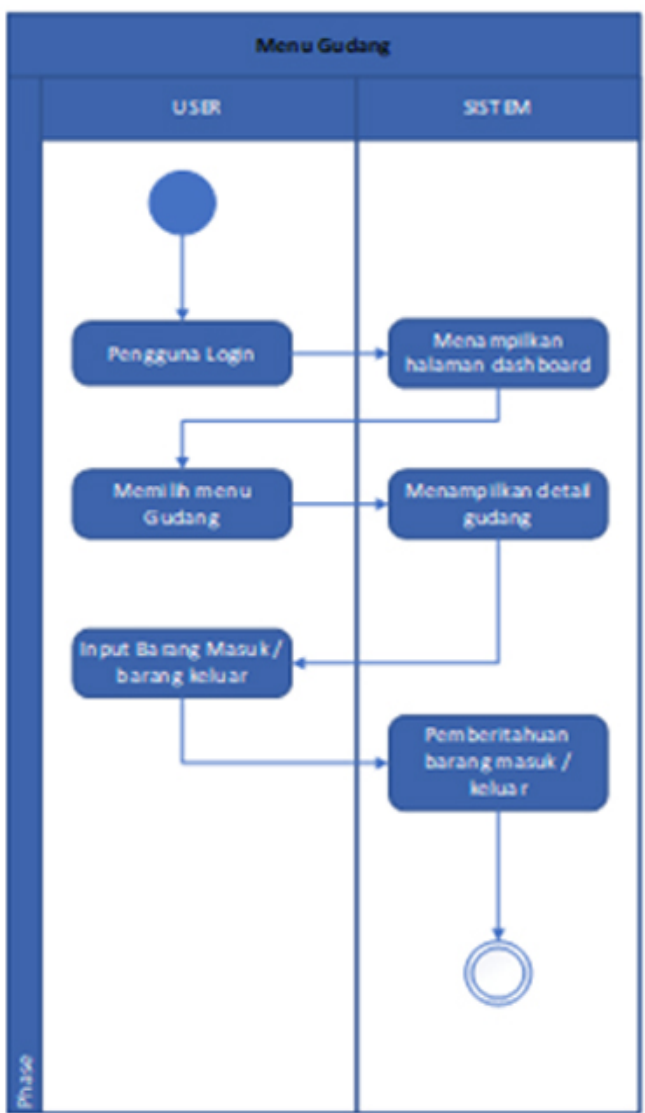

(b) Activity Diagram Menu Gudang

Gambar 3. Activity Diagram 


\subsection{Class Diagram}

Class Diagram adalah sebuah spesifikasi yang jika diinstansiasi akan menghasilkan sebuah obyek dan merupakan inti dari pengembangan dan desain berorientasi obyek. Class menggambarkan keadaan (atribut/properti) suatu sistem, sekaligus menawarkan layanan untuk memanipulasi keadaan tersebut (metoda/fungsi)[8].Class Diagram untuk sistem sistem informasi penjualan dan prioritas pengadaan mempunyai 10 class yaitu, harga, promethee, preferensi, cabang, user, invoice, detail_invoce, produk, kategori_produk, gudang dan mempunyai 5 method global yaitu add(), ViewALL(), update(), delete() dan juga $\operatorname{get}()$.

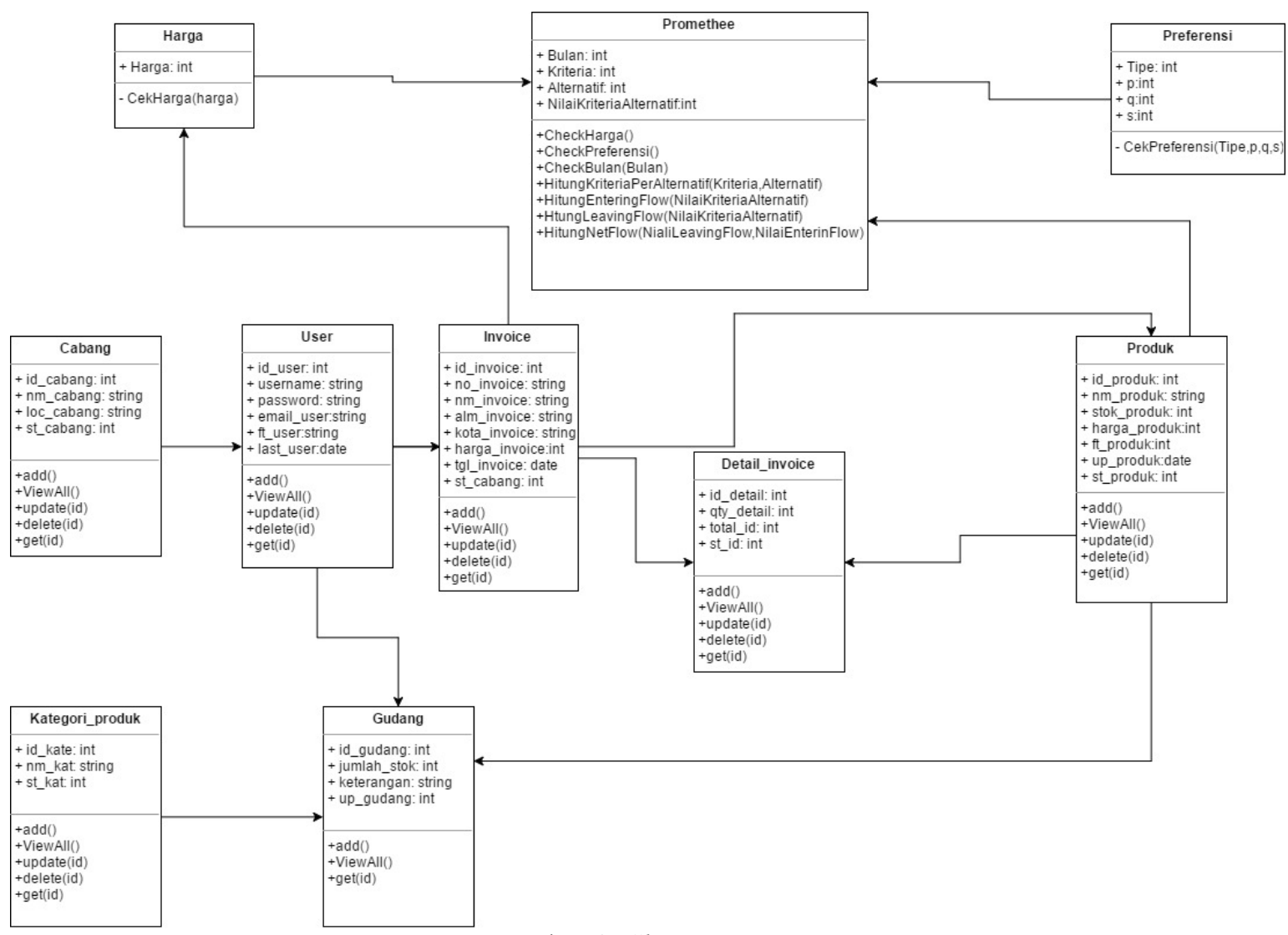

Gambar 4. Class Diagram

\subsection{Entity Relatioship Diagram (ERD)}

Pada gambar 5(a) database terdapat 2 database yang digunakan yaitu database untuk mencatat master dan juga segala transaksi dan database untuk metode promthee. Pada database penjualan terdapat 9 tabel yang saling berhubungan dan masing-masing tabel memiliki fungsi yang berbeda-beda tabel satu adalah "cabang" tabel master untuk menyimpan seluruh cabang yang dipunyai oleh UD.Motto Racing Surabaya seperti, Pusat, Jatim, Jateng dan seluruh cabang lain yang ada di Indonesia.

Tabel yang kedua yaitu "kategori produk" tabel master untuk menyimpan kategori - kategori produk, tabel yang ketiga adalah "produk" tabel master untuk menyimpan barang - barang yang dijual di UD.Motto Racing Surabaya, tabel keempat adalah tabel "pelanggan" tabel master untuk menyimpan data - data pelanggan yang telah berlangganan dengan UD.Motto Racing Surabaya.

Tabel yang kelima yaitu "user_level" tabel master untuk menyimpan level akses user yang akan mengakses sistem. Tabel yang ke-enam adalan tabel "user" tabel master untuk menyimpan user- user yang bisa mengakses sistem, tabel yang ketujuh adalah tabel "invoice" tabel transksasi untuk menyimpan nota - nota penjualan, selanjutnya tabel yang ke-delapan adalah tabel "detail_invoice" tabel yang berisi barang - barang yang terjual pada tabel invoice. Tabel yang terakhir adalah tabel "gudang" tabel transaksi untuk mencatat barang - barang yang masuk maupun yang keluar pada gudang di UD.Motto Racing Surabaya. 
Gambar 5(b) adalah database promethee, terdapat 5 tabel yang saling berhubungan dan masingmasing tabel memiliki fungsi yang berbeda-beda, tabel pertama yaitu tabel "pro_alternatives" yang berfungsi untuk menyimpan nama - nama alternatif dari barang yang di urutkan prioritas pengadaan barangnya.

Tabel kedua adalah tabel "pro_types" yaitu tabel yang berisikan tipe - tipe preferensi dari metode promethee, tabel yang ketiga adalah "pro_krtieria" berfungsi untuk menyimpann kriteria - kriteria yang ada, tabel keempat adalah "pro_sub_crtieria" tabel yang berguna untuk menyiman sub kriteria yang ada sekaligus parameter - paremeter seperti p, q, s dan juga tipe prefernsi yang di miliki. Tabel yang terkahir adalah tabel "pro_evaluations" yaiu tabel yang berisi value - value / nilai - nilai dari masing - masing alternatif.

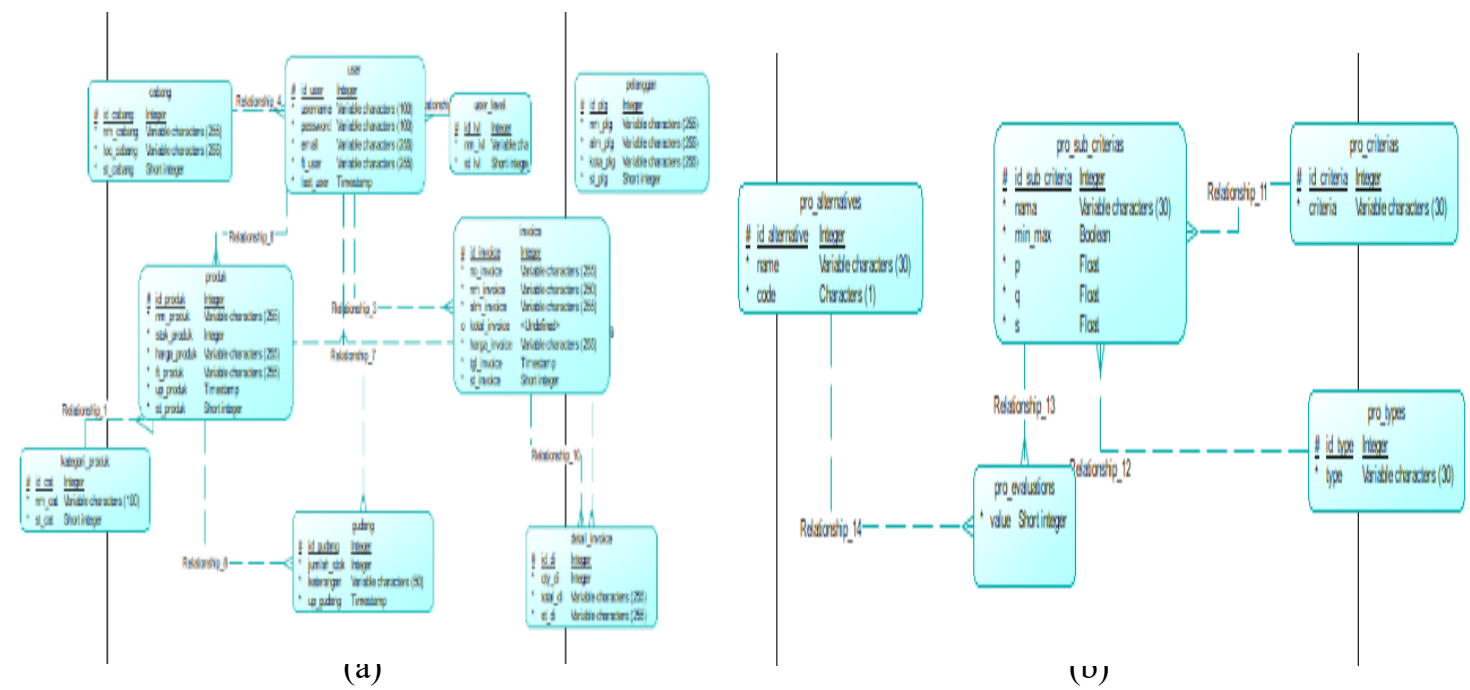

Gambar 5(a) Database Penjualan, 5(b) Database Promethee

\subsection{User Interface}

Tampilan dashboard untuk admin gudang, tampilan dashboard berisikan detail - detail berapa barang yang masuk, berapa banyak barang yang keluar, dan kapan barang tersebut masuk ataupun keluar, untuk menampilkan detail barang masuk dan keluar pada Gudang ditunjukkan pada gambar 6(a). Tampilan dashboard untuk kasir, tampilan dashboard berisikan detail - detail invoice termasuk status invoice, nama pembeli, alamat, total harga invoice, kasir yang melayani, dan dicabang mana invoice tersebut ditunjukkan pada gambar 6(b). Tampilan rekomendasi prioritas pengadaan barang menunjukan hasil perhitungan promethee terhadap kebutuhan pengadaan prioritas barang ditunjukan pada gambar 6(c).
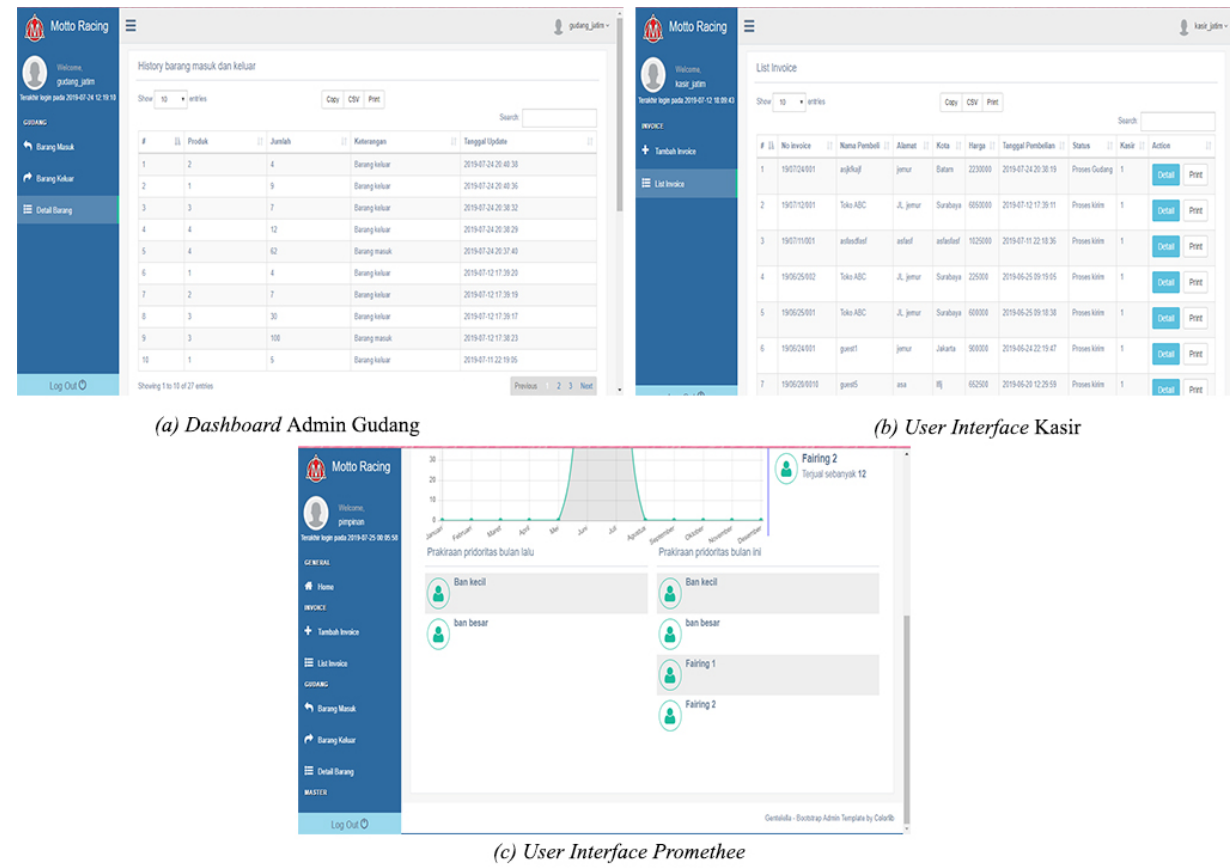

Gambar 6. User Interface Sistem 


\section{Pengujian}

\subsection{Pengujian Akurasi}

Table 1. Confustion Matrix

\begin{tabular}{|c|l|l|}
\hline Ristem & \multicolumn{1}{|c|}{ TRUE } & FALSE \\
\hline TRUE & True Positive (TP) & False Positive (FP) \\
\hline FALSE & False Negative (FN) & True Negative (TP) \\
\hline
\end{tabular}

Dari penjelasan tabel diatas didapatkan rumus accuration :

Keterangan:

$$
\begin{array}{ll}
\mathrm{TP} & =\text { True Positive } \\
\mathrm{TN} & =\text { True Negative } \\
\mathrm{FP} & =\text { False Positive } \\
\mathrm{FN} & =\text { False Negative }
\end{array}
$$$$
\text { accuration }=\frac{T P+T N}{T P+T N+F N+T P} * 100 \%
$$

- Bulan April

Data tepat $=4$ barang, data tidak tepat $=2$ barang accuration $=\frac{4+0}{4+0+2+0} * 100 \%=\frac{4}{6} * 100 \%=66,66667 \%$

- Bulan Mei

Data tepat $=5$ barang, data tidak tepat $=1$ barang

accuration $=\frac{5+0}{5+0+1+0} * 100 \%=\frac{5}{6} * 100 \%=83,33333 \%$

- Bulan Juni

Data tepat $=3$ barang, data tidak tepat $=3$ barang accuration $=\frac{3+0}{3+0+3+0} * 100 \%=\frac{3}{6} * 100 \%=50 \%$

- Bulan Juli

Data tepat $=5$ barang, data tidak tepat $=1$ barang

$$
\text { accuration }=\frac{5+0}{5+0+1+0} * 100 \%=\frac{5}{6} * 100 \%=83,333333 \%
$$

Pada bulan Mei mengalami kenaikan presentase akurasi diakibatkan adanya lonjakan pesanan pada bulan itu dikarenakan mendekati hari raya idul fitri sedangkan pada bulan Juni mengalami penurunan presentase dikarenakan menurunnya pesanan akibat libur hari raya idul fitri yang cukup lama dan pengiriman barang sedikit terlambat. Dan pada bulan Juli mengalami kenaikan kembali dikarenakan pesanan telah stabil kembali dibandingkan bulan sebelumnya, rata - rata tingkat akurasinya sebesar $70,83 \%$ berikut adalah grafik tingkat akurasi dari bulan April - Juli 2019.

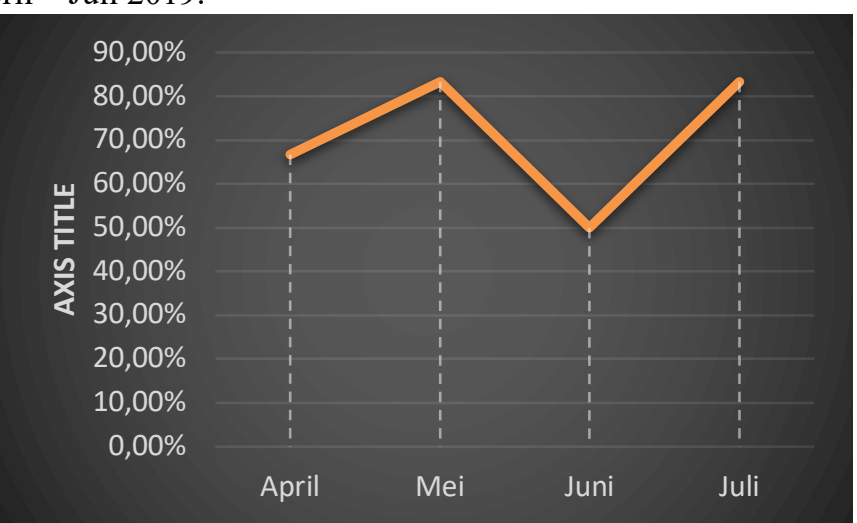

Gambar 8. Grafik Tingkat Akurasi 
Untuk mengukur klasifikasi kelayakan dapat dikur dengan skala pengukuran produk pada tabel 2 :

Table 2. Klasfikasi Kelayakan

\begin{tabular}{|l|l|l|}
\hline No & Persentase Pencapaian & $\begin{array}{l}\text { Klasifikasi } \\
\text { kelayakan }\end{array}$ \\
\hline 1 & $81 \%-100 \%$ & Sangat Layak \\
\hline 2 & $61 \%-80 \%$ & Layak \\
\hline 3 & $41 \%-60 \%$ & Cukup Layak \\
\hline 4 & $21 \%-40 \%$ & Tidak Layak \\
\hline 5 & $0 \%-20 \%$ & Sangat Tidak Layak \\
\hline
\end{tabular}

Pada pengujian diatas tingkat akurasi rata -rata pada prioritas pengadaan barang mencapai 70,83\% yang menunjukan bahwa klasifikasi kelayakan "Layak" yang berarti dapat di implementasikan secara riil.

\subsection{Pengujian Blackbox}

Tabel 3 merupakan data pengujian blackbox dalam penelitian sistem informasi penjualan dan prioritas pengadaan barang berbasis web dengan metode promethee. Dimana semua fungsi telah berjalan $100 \%$ secara normal.

Table 3. Pengujian Blackbox

\begin{tabular}{|c|l|c|c|}
\hline No & \multicolumn{1}{|c|}{ Kegiatan } & Valid & Tidak Valid \\
\hline 1 & Login Sistem & $\sqrt{ }$ & \\
\hline 2 & View data produk & $\sqrt{ }$ & \\
\hline 3 & Mengubah Data produk & $\sqrt{ }$ & \\
\hline 4 & Menghapus Data produk & $\sqrt{ }$ & \\
\hline 5 & Menambahkan Data produk & $\sqrt{ }$ & \\
\hline 6 & Menambahkan invoice & $\sqrt{ }$ & \\
\hline 7 & Mencetak invoice & $\sqrt{ }$ & \\
\hline 8 & View data gudang & $\sqrt{ }$ & \\
\hline 9 & Menambahkan barang masuk & $\sqrt{ }$ & \\
\hline 10 & Menyetujui barang keluar & $\sqrt{ }$ & \\
\hline
\end{tabular}

\section{Kesimpulan}

Kesimpulan yang di dapatkan bahwa metode promethee bisa diterapkan pada prioritas pengadaan barang beradasarkan pada hasil pengujian tingkat akurasi rata -rata pada prioritas pengadaan barang mencapai $70,83 \%$ yang menunjukan bahwa klasifikasi kelayakan sistem "Layak" yang berarti sistem dapat di implementasikan secara riil.

\section{Daftar Pustaka}

[1] W. K. Muhammad Wafi, Rizal Setya Perdana, "Implementasi Metode Promethee II untuk Menentukan Pemenang Tender Proyek (Studi Kasus: Dinas Perhubungan dan LLAJ Provinsi Jawa Timur),” J. Pengemb. Teknol. Inf. dan Ilmu Komput., vol. Vol. 1, 2017.

[2] J. Dong and S. Wan, "A PROMETHEE-FLP Method for Heterogeneous Multi-Attributes Group Decision Making,” IEEE Access, vol. 6, pp. 46656-46667, 2018.

[3] T. Chen, "A Novel PROMETHEE-Based Outranking Approach for Multiple Criteria Decision Analysis With Pythagorean Fuzzy Information,” IEEE Access, vol. 6, pp. 54495-54506, 2018.

[4] M. Jes, J. A. Lozano-miralles, and R. Lopez-garcia, "Environmental Criteria for Assessing the Competitiveness of Public Tenders with the Replacement of Large-Scale LEDs in the Outdoor Lighting of Cities as a Key Element for Sustainable Development : Case Study Applied with PROMETHEE Methodology,” MDPI, vol. 11, 2019.

[5] H. Liu, "Failure Mode and Effect Analysis Using Cloud Model Theory and PROMETHEE Method," vol. 66, no. 4, pp. 1058-1072, 2017.

[6] M. Bottero, C. D. Alpaos, and A. Oppio, "Multicriteria Evaluation of Urban Regeneration Processes : An Application of PROMETHEE Method in Northern Italy," vol. 2018, 2018.

[7] R. Arsita, "Sistem Pendukung Keputusan Penerimaan Jaminan Kesehatan Masyarakat (JAMKESMAS) Dengan Metode Promethee. Program Studi Teknik Informatika STMIK Budi Darma: Medan.," 2013.

[8] Nugroho. A., Analisis dan Perancangan Sistem Informasi dengan Metodologi Berorientasi Objek. Bandung: Informatika, 2005. 